\title{
Aviation industry management: objective and subjective risks
}

\author{
Mariia Abysova ${ }^{1}$, Tetiana Shorina ${ }^{1,}{ }^{*}$, Nataliia Chenbai $^{1}$, and Ivan $\mathrm{Skyba}^{1}$ \\ ${ }^{1}$ National Aviation University, 1 Liubomyra Huzara ave., Kyiv, 03058, Ukraine
}

\begin{abstract}
The paper studies objective and subjective risks of the Ukrainian economy, in particular in the field of aircraft construction, and the transformation of industrial management. Objective risks we considered in connection with the processes of de-industrialization of the Ukrainian economy and the transformation of its structure, taking place over the past few decades. Subjective risks are considered in connection with the peculiarities of thinking, which have found their expression in the form of industrial management. We find that in the face of declining industrial volumes the administrative public management is aware of the need to develop the aviation industry and has an adopted Strategy for the Revival of Domestic Aircraft Construction. However, in the course of analyzing the control documents, we found that there is a known imbalance between real experience and the desired declarative intention. In this, we see the danger of subjective management risks. We see that due to the external market situation the subjects of Ukrainian industrial management have a small range of solutions. We hope for the implementation of creative, ambitious, and at the same time realistic organizational, functional, legal, scientific, and technical tools that will serve as drivers for new reindustrialization and social innovation.
\end{abstract}

\section{Introduction}

The state of the aviation industry is one of the important factors that determine the level of development and influence of a country in the modern world, its status as a highly developed scientific and technological state. Besides, the development of the aviation industry is an integral link in the system of strengthening the defence capability of the state and ensuring its security. Aviation production has a powerful potential for scientific, technical, and technological innovations, being at the same time a large consumer of them. From the point of view of the basis of the innovative and technological development of the economy, the aviation industry importance cannot be overestimated - the scale and range of its scientific, technical and technological achievements and interests are dramatically great. The science-intensive technologies used in the economy create a large number of jobs both at their enterprises, and in related industries. Such productions are highly profitable, with a load of orders, their budgetary efficiency is very high. At the same time, in the situation of market adaptation, it is more and more difficult for national governments to find and

\footnotetext{
* Corresponding author: miravam03@gmail.com
} 
propose answers that arise in connection with problems in industry and in connection with high global competition. The Ukrainian economy is experiencing a difficult situation of entering the international division of labour, reflected in the entire production spectrum, including aviation industry problems. In this regard, the importance of effective industrial management, state and private financial support is becoming more acute.

\section{Materials and methods}

Industrial management is considered to be a certain type of economic policy, along with such types as stabilization, financial, trade, etc. ones. However, unlike the types mentioned above, which have a general economic character, industrial management is designed to promote industries where interference must take place for reasons of national independence, technological autonomy, failures of private initiative, the decline of traditional activities, geographic or political balance" [1]. Some experts agree that industrial policy is of a sectoral nature: industrial policy is basically any type of selective intervention or government policy aimed at changing the sectoral structure of production towards industries that, are expected to offer better prospects for economic growth than in the absence of such intervention, i.e. in a market equilibrium [2].

J. Foreman-Peck, who performed a retrospective analysis of European industrial policy in the XX century, refers exclusively manufacturing industries and infrastructure industries to its sphere. And while he believes that the term "industry" can in principle be extended to any source of employment - either to mining, or agriculture, or the service industry (assuming that job classification is relatively arbitrary) - but government policies in relation to agriculture and services in general differed from policies in relation to industry, defined more strictly, and therefore the field of study should be limited to be managed" [3].

In the paper, the authors investigate objective risks of the Ukrainian economy, in particular in the field of aircraft construction, and the transformation of industrial management. Objective risks associated with the peculiarities of the industrial development of Ukraine, which are being formed under the influence of the globalization processes and the neo-liberal world economy. In authors' opinion, the structure of the Ukrainian economy and its place in the world division of labour are significant parameters in understanding the country's competitive advantages. Subjective risks bound up with the peculiarities of thinking find their expression in the form of industrial management, in the form of tasks and strategies that are formulated to solve state and economic problems, and, finally, in the form of strong-willed readiness to perform assigned tasks. The authors aim at tracing the conformity of the declarative goals of the Strategy for the Revival of Domestic Aircraft Construction (2018) to the real production and organizational capabilities. The planned task will be done on the example of the key aircraft manufacturer - the "Antonov" State Enterprise.

Initially, it should be noted that the Ukrainian economy has been experiencing a decline in its socio-economic indicators for several decades in a row. Its current position is reflected in hypertrophied trend towards an increase in the share of the service sector. This trend is not a consequence of approaching a post-industrial society, but the result of destructive de-industrialization $[4,5]$. 


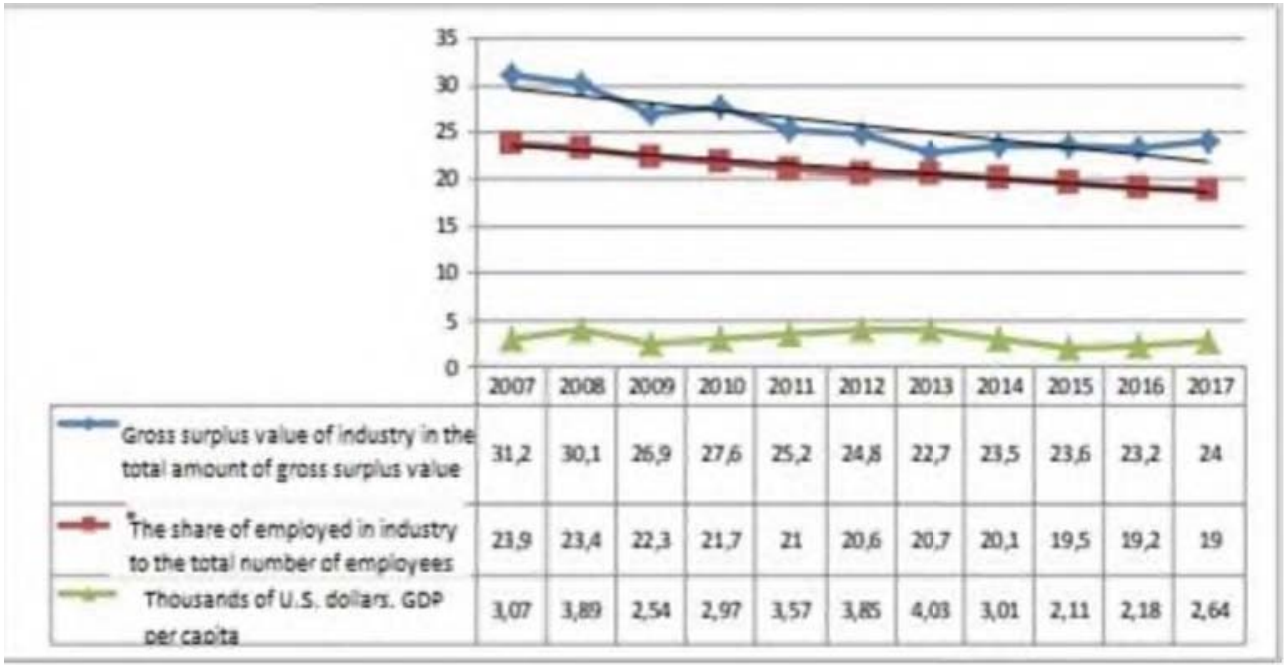

Fig. 1. Dynamics of indicators of the role of industry in the economy of Ukraine (2007-2017).

The study of the industrial policy transformations led to the conclusion that the industrial policy was usually understood as actions of a direct state intervention in the economy, as the exercise of directive control by the government over the production apparatus until the 80 s of the XX century; these days this mechanism has been changed. Nowadays, the industrial policy is more likely to be understood as a variety of policies that are implemented by various institutional actors in order to stimulate the creation of firms, in favour of their concentration, to promote innovation and competitive development in the context of an open economy. Therefore, the new industrial policy is mainly an industrial development policy in which the industry is implicitly viewed as an institution and strategic management of human competencies and technical capabilities [6].

The authors of the article turned to philosophical intentionalism as a methodological principle. According to this principle, any action should be evaluated in terms of its purpose. Therefore, the theoretical foundations of only those actions that have the intention to influence the industry are considered. This means that both "vertical policy" will be taken into account - in the part that aims at changing the relative importance of industry as a whole and/or its individual industries, and "horizontal policy" - in the part that concerns institutions, innovations and etc. in industry.

\section{Results}

Modern large-scale changes in the world economy cover the basic technologies of material production, forms of its social organization, socio-economic relations and informationcommunication interactions. The international division of labour and the organizational structures of world production and trade associated with it are actively changing. New "growth poles" and new outsiders are dynamically emerging. Significant changes are taking place in the competitive environment of the market form of management - both in individual national economies and in interstate regions and the world economy as a whole. As a result, many industrialized countries have lost their positions as world leaders in the development, production, and sale of industrial products, and faced new risks of losing a number of industries, technological dependence, and social tension. Hence, the relevance of industrial management as a form of realizing national interests in the sphere of industrial 
production of material goods, which is the basic factor of national competitiveness and economic security, increases.

In Ukraine, industrial management is taking place in the context of a decline in industrial production. Moreover, the analysis of the structure of the latter indicates a continuing decline in the share of mechanical engineering with an increase in the share of raw materials industries. In 2010, it was four times less than in 1990 [4]. In addition to falling GDP, a side effect of a weakening economy is a reduction in jobs, a decrease in the quality of human resources, a massive "transition" to the service sector or labour migration of the most qualified and economically active population.

Of course, in order to preserve economic security, Ukraine needs to set ambitious goals and revise its economic doctrine to resume its industrial component. An economic breakthrough can be the development of high technology industries, among which the aviation industry occupies the most important place.

Ukraine remains one of the nine countries in the world with the entire production cycle of passenger, military transport, and transport aircraft. Ukraine inherited from the USSR a powerful aviation industry, which built up to 250 aircraft (An-24, An-26, An-32, An-124, An-225, Tu-134, An-72, An-74 and their modifications) annually. Since the independence of Ukraine, state funding for the aviation industry has been significantly reduced and the aviation industry has begun to experience chronic difficulties. The state enterprise "Antonov", as the flagship of the aircraft industry in Ukraine received more than $90 \%$ of its total revenue from the cargo airline "Antonov Airlines", its structural unit, which provided the enterprise with non-budgetary funding. Mainly due to proceeds from these funds, the aviation industry of Ukraine maintained its existence. In independent Ukraine at work of $P$ Balabuev acting as the general designer of "Antonov" several new types of An-70, An-38, An-140, An-148 aircraft were created, An-124 aircraft was purchased for the airline, and the mentioned above and An-225 aircraft were modernized and certified for operation on international markets. A complex of works was carried out to increase carrying the capacity of the An-124-100 aircraft from 120 to 150 tons, a new navigation complex was created and the number of crew-members was reduced. Composite materials, digital technologies were introduced for new aircraft, etc. However, already for the period 2005-2014, not a single new type of aircraft has been created in Ukraine, and design bureaus do not have fundamentally new developments. Ukrainian heavy industry, and, in particular, the aircraft industry is going through times of crisis and further degradation.

The Ukrainian economy still fails to overcome systemic imbalances:

- structural: the predominance of low-tech energy and resource-intensive industries in the structure of the Ukrainian industry;

- functional: lack of reliable mechanisms of state regulation of industrial development;

- target: inconsistency of the current state of Ukrainian industry with the goals of noindustrialization and the development of advanced production;

- imbalance between the system and the external environment due to excessively high environmental costs of industrial production [7].

The traditional Soviet industrial management was characterized by a sectoral (vertical) approach, i.e. it was focused on selective stimulating of the development or support of certain industries (types of activity) in order to improve certain industrial and general economic indicators (increase in industrial production, enhancement of its profitability, growth of employment, improve the trade balance, etc.). In modern Ukraine, in the context of the priority of horizontal (inter-sectoral) measures to promote the goals of economic development, individual enterprises, their associations, etc. are not able to eliminate the crisis phenomena in industry independently due to their systemic nature, and therefore are forced to adapt to unfavourable conditions of economic activity. 
In the model of neoclassical economics, adopted by Ukraine from the West, the free competition of economic actors rationally acting in their own interests leads to the efficient use of limited resources. The rationale for government intervention in this market mechanism arises when there are obstacles to free competition, known as market failures [8]. However, this intervention itself can also be associated with failures, but now of the state (government failures). In the context of industrial policy, such failures of the state, along with conflicts of industrial policy of the state with other types of economic policy, self-serving behaviour of officials, can also include imperfect information [9]. Administrative bureaucracy can generate imperfect information. Unlike those economic actors who are directly involved in market transactions, the bureaucracy is less aware of the costs and benefits of this or that business, the ways of its development: "... the public sector is not omniscient, and, as a rule, it is even less informed than the private sector, about the location and nature of market failures that block diversification. The government may not even know what it does not know in actual fact" [10].

The ignorance of public authorities is also associated with the comprehension and production of the trans-ideological political field, that is, one going beyond ideologies when in the absence of universal normative criteria of the truth there is a place for any discourse in the picture of the world. Meanwhile, the discourse of the Western postmodern society, to which the socio-cultural periphery looks to as the avant-garde, is assessed as the standard among them. "How can this phenomenon be estimated? In the tradition of Enlightenment optimism, it can be assessed positively - as an exchange of "advanced achievements" and the implementation of the Enlightenment-modernizing mission of the developed towards the backward. However, from the point of sociocultural realism view, here you can see the source of the creeping catastrophe. Indeed: from the fact that the field of claims is levelled according to the standards of highly developed countries, it still does not follow that the corresponding opportunities are levelled" [11].

On July 8, 2020, the Ukrainian government updated the Strategy for the Revival of Domestic Aircraft Construction (2018) by amending the action plan for its implementation and extended the implementation of the Strategy until 2030 [14]. Nevertheless, the goals indicated in the document look declarative and abstract, taking into account the weak financial and economic position of the state and the level of global competition. Let us point out these goals:

1) Support for the national producer.

2) Improving the competitiveness of aircraft products.

3)Implementation of structural changes, in particular, the transformation and privatization of enterprises, the creation of integrated management structures of the industry.

4) Development of new aircraft and helicopters and modernization of existing types of aviation equipment, which will be in demand on the market.

5) Restructuring, modernization, and technical re-equipment of production facilities.

6) Creation and introduction into serial production of fundamentally new technologies and means of their implementation at enterprises producing aviation equipment.

7) Creation of favorable conditions for the sale of manufactured aircraft, the introduction of effective schemes for its implementation, in particular with the introduction of leasing schemes [15].

Let's analyze these goals on the example of the main manufacturer of aircraft - the "Antonov" State Enterprise. The company remains a leader in Ukrainian aircraft construction; it makes single deliveries to different countries, develops and designs aircraft for various purposes, but has a competitive advantage in the production of regional passenger and medium and heavy transport aircraft. For the economic analysis, the 10 most important indicators were selected, which allow us to assess the state of the company, the 
level of its activity, and position among other enterprises. The initial data for the analysis are shown in Table 1 represented by N Skorobohatova and A Korchak [16].

Table 1. Matrix of initial data of enterprises (2014).

\begin{tabular}{|c|c|c|c|c|c|c|c|c|c|c|}
\hline 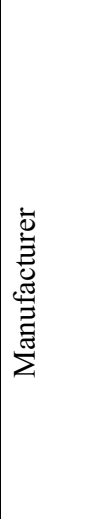 & 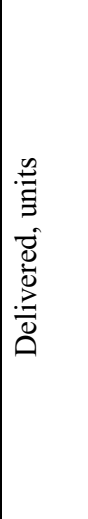 & 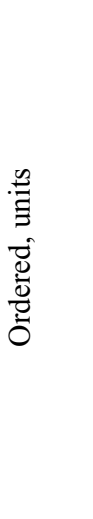 & 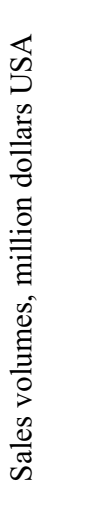 & 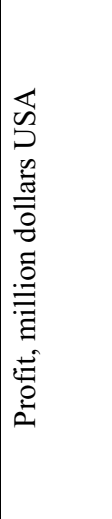 & 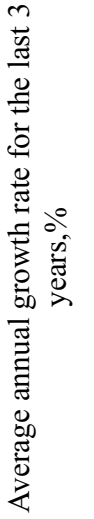 & 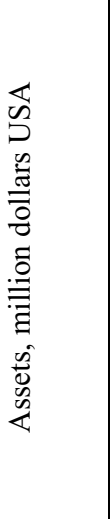 & 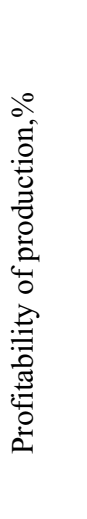 & 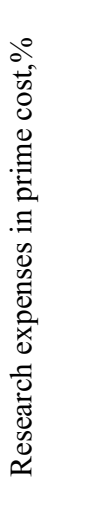 & 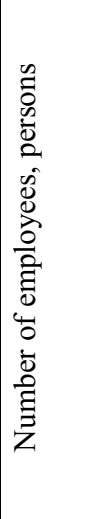 & 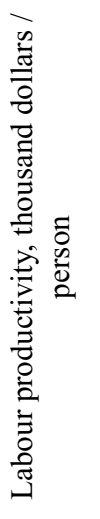 \\
\hline & 1 & 2 & 3 & 4 & 5 & 6 & 7 & 8 & 9 & 10 \\
\hline Boeing & 723 & 1432 & 90762 & 5446 & 5.5 & 99198 & 18.3 & 4 & 165500 & 548.4 \\
\hline $\begin{array}{l}\text { Airbus } \\
\text { Group }\end{array}$ & 629 & 1456 & 80657 & 3122 & 0.4 & 127672 & 17.3 & 6.5 & 138622 & 581,8 \\
\hline $\begin{array}{l}\text { Bombar } \\
\text { dier }\end{array}$ & 84 & 282 & 20111 & (1246) & 3.9 & 27614 & 14.7 & 2 & 73950 & 271.9 \\
\hline $\begin{array}{l}\text { Antono } \\
\text { v SE }\end{array}$ & 2 & 5 & 282 & 3,3 & -23.5 & 511 & 11.4 & 13.4 & 12893 & 21.9 \\
\hline
\end{tabular}

As can be seen from the above data, the main problem holding back the company's development is the lack of serial production. It is believed that to establish break-even production, the company should produce 25-30 aircraft per year. Since the "Antonov" State Enterprise has been making a small profit in recent years, it can be argued that the company receives it through the operation of "Antonov Airlines".

Among other problems that hinder the activities of enterprises is the need to support the operation of Ukrainian aircraft in the world. It is necessary to ensure the sale of not just an aircraft, but also a product that would include maintenance, leasing, training and retraining of pilots and other related services. Opening such service centres would help gain the trust of potential consumers.

In addition, a negative factor holding back the activities of the "Antonov" SE is the lack of interest and demand in the domestic market. The enterprise is able to meet the demand of the state and Ukrainian airlines in full, however, these business entities are inclined to supply their aircraft from foreign companies. Positive shifts in this direction have been outlined since 2015, when the company finally received some orders from the Ministry of Defence of Ukraine. In the future, the implementation of existing orders and, possibly, the receipt of new ones.

Another significant reason for lagging behind the leaders is the lack of investments that would provide confidence for the company and renew the company's working capital. 
No less important problems are the technical obsolescence of production facilities and the inefficiency of the process of import substitution of equipment made in The Russian Federation [17].

Has the situation changed for the better in five years? The report on the results of the analysis of the effectiveness of the application of tax benefits by business entities and their impact on the development of aircraft construction gives an idea of this. Indicative in this regard is also the report on the management of SE "Antonov" for 2019 [16]. The last document in section 6 entitled "Risks" lists the main risks of airlines:

1. Long-term absence of the state defence and consolidated order for the development of aircraft and simulators, their production and supply, which significantly reduces the inflow of funds to the enterprise.

2. The need to obtain Certificates such as the European Aviation Safety Agency (EASA) for advanced aircraft An-148, An-158, An-178, An-132, etc., which limits their sales to EU countries and countries in which these certificates are recognized without extra work.

3. Insufficiently developed infrastructure of after-sales service of aircraft customers, which hinders their sales.

4. Low solvency of domestic airlines to purchase "An" aircraft, insufficiently efficient leasing system $[\ldots]$.

5. Absence of the State Target Scientific-Technical Program of Development of the Aviation Industry of Ukraine in which solutions of the basic problems of the aviation industry enterprises, including existence of considerable demand for existing and perspective "An" planes, the necessity of completion of import substitution programs, development of new breakthrough products An-1X8 aircraft are included [...].

6. Loss of traditional markets for aircraft, which is currently not compensated in the markets of the EU and other countries.

7. In the presence of the Export Credit Agency [...] no mechanism has been developed to ensure, guarantee and reduce the cost of lending to aircraft exports.

8. Insufficient capacity of the financial system of Ukraine (banks) in terms of providing funds in the required amounts at attractive interest rates and duration for the implementation of long-term aviation projects of the industry, for the purchase of aircraft by airlines and leasing companies.

9. High cost of loans, complexity and duration of their receipt by the state enterprises of the aircraft industry [...].

10. In Ukraine, attractive conditions for the import of new and "used" foreign aircraft of Western manufacturers have been created, which in comparison with the new Ukrainian aircraft has price advantages [...].

11. There is no procedure for the distribution of funds for the implementation of Article 31 of the Law of Ukraine "On the development of the aircraft industry" of July 12, 2001, № 2660-IP [...].

12. Lack of an effective system of stimulating demand for aircraft in Ukraine.

13. Lack of a mechanism in Ukraine to stimulate Ukrainian air carriers in the acquisition and operation of domestic aircraft in terms of preferences (benefits) for the payment of taxes, airport fees, air navigation services, etc.

14. Lack of industry science that hinders the creation of competitive aircraft.

\section{Discussion}

The continuing decline in all indicators of the Ukrainian aviation industry looks like an unregulated adaptation of the country's economy to the needs of the world economy. A feature of the modern world economy is globalization, which has replaced the 
internationalization of production. If the internationalization of national economies makes world economic ties a permanent factor in the economic growth of states at different stages of development, then globalization turns these ties into a decisive factor in the progress of national economic complexes, whose further changes are increasingly determined by the tasks of guaranteed sales of products beyond national borders. In principle, in moving towards advanced production, the task of improving technologies and products that have already been mastered in production and have relatively stable or growing sales markets is solvable. This presupposes a concentration of efforts on those types of activity in which the national producer already has competitive advantages (natural or artificial). The specificity of the range of products of Ukrainian aircraft factories, which has historically developed, is that the profile products for Ukrainian enterprises are transport and passenger aircraft for regional and medium-haul lines. This allows Ukrainian manufacturers to diverge in different market niches with the world's largest aircraft manufacturers. For example, Romania, which is not considered an aircraft-building country, assembles components for Boeing aircraft. The British analyst B Moores also believes that it would be more profitable for Ukraine to become a supplier to large companies. "It's not necessary to make your own plane! You can make, for example, toilets for air-planes and earn much more money on it," he says. However, he adds that now is a very bad time to become a supplier, because large companies have already chosen suppliers for the next ten years [17]. As follows from the analysis of Strategy for the Revival of Domestic Aircraft Construction (2018), Ukraine, at the level of intentions, is not going to give up its status of a state capable of producing the final product - either transport or passenger aircraft, as well as various components. However, such statements presuppose scientific and technical rationale and institutional support, including the creation of an institution of government orders, protection of markets from importers, for example, through the mechanism of export credit agencies, of a general enthusiasm for the development of scientific engineering. Nevertheless, as indicated by the documents of the report of the Accounts Chamber "On the results of the analysis of the effectiveness of the use of tax incentives by business entities and their impact on the development of aircraft construction" dated May 28, 2019, No. 12-3, the Concept of the State Target Scientific and Technical Program for the Development of Aviation industry for 2018-2022, the State Target Scientific and Technical Program for the Development of the Aviation Industry for 2018-2022 has not been approved, as provided for in paragraph 15 of the specified action plan [18]. In addition, due to underdeveloped legislation, neither in 2018 (as planned), nor in 2019, an export credit agency was launched, although the Cabinet of Ministers approved the necessary constituent documents. All this, in our opinion, casts doubt on the feasibility of the proposed intentions and strategic plans. We state declarative statements and promises, but we do not meet a real mechanism and strong-willed determination of the management leadership to solve such complex problems systematically. Long-term strategies require systematic and long-term work, but frequent changes of government bodies and state perturbations in the country in recent years does not contribute to such a mode of operation. Moreover, according to experts, the international treaties signed by Ukraine on world trade, in particular on the WTO, the Free Trade Association, are drawn up from positions that consolidate Ukraine's position as a weaker economy in front of the rights and opportunities of the world's strongest economies. This state of affairs also raises questions about the ability of government agencies and private businesses to support and protect domestic exporters. In this sense, high-tech breakthroughs in the processing industry while maintaining unfavorable trade preferences are unlikely to take place. 


\section{Conclusion}

In the paper, the authors have investigated objective and subjective risks of the Ukrainian economy, to be precise, in the field of aircraft construction, and the transformation of aviation industrial management. Objective risks are researched in connection with the deindustrialization processes of the Ukrainian economy and its structure transformation, taken place over the past few decades. The decline in the share of processing industries, especially machine building, in the industrial structure negatively affects the competitive capabilities of the national economy in the niche of world trade-in high-tech products and consolidates its dependence on alien propositions. Deindustrialization directly correlates with GDP per capita indicators, showing a negative trend towards a decrease in the economic well-being of the population with reference of a decrease in production volumes. All this has a depressing effect on the labor and production-scientific potential of the state. Under these conditions, successful industrial management could be associated with sectoral support for the economy, including support for the aviation industry. The authors have shown that the administrative public management is aware of the need to develop the aviation industry; and it has an adopted Strategy for the Revival of Domestic Aircraft Construction. The programs that kind testify to subjective plans and intentions, to the ability of management to assess a problem situation, find promising solutions, and make active efforts to implement them. At the same time, the control documents and reports on the activities of the leading aircraft manufacturer - the "Antonov" State Enterprise show, there is an obvious imbalance between a real experience and the desired declarative intention. On this count, the danger of subjective risks is emerging. An unbalanced consciousness enters into inconsistency with the assumed obligations and is not able to offer a real mechanism for the implementation of their plans. In the style of administrative industrial management, the authors, therefore, find signs of inertial and rigorous thinking. In authors' opinion, the subjects of industrial management cannot but take into account the conjuncture of the world market and the structure of the world division of labor, realizing the lag of the possibilities of Ukrainian aviation products. The intentions to preserve the previous achievements of the aviation industry of the first decade of Independence seem unrealistic. On the other hand, the passive doctrine of the expectation of a favorable situation in the world market, integration into its structure on unequal conditions, closes broad prospects for the socio-economic development of the state. There remains a small range of solutions, but there is a hope for the implementation of creative, ambitious, and at the same time realistic organizational, functional, legal, scientific, and technical tools that will serve as drivers for new reindustrialization and social innovation.

\section{References}

1. E. Cohen, EIB Papers 1(11), 86 (2006)

2. H. Pack, K. Saggi, World Bank Research Working Paper 3839, 2 (2006)

3. J. Foreman-Peck EIB Papers 1(11), 38 (2006)

4. A. Zadoya, Academic Review. 1(36), 29 (2012)

5. I. Pasinovich, O. Sych, Regional Economy 1, 59 (2019)

6. P. Bianchi, S. Labory, International handbook on industrial policy, chapter XV, 12 (Edward Elgar, Cheltenham, UK, Northampton, MA, USA, 2006)

7. V. P. Vyshnevskiy, A. I. Amosha, L. A. Zbarazskaia, A. A. Okhten, D. Iu. Cherevatskiy, Industrial policy and management of industrial development in the 
context of systemic imbalances: conceptual foundations, 180 (Institute of Industrial Economics, Donetsk, 2013)

8. P-A. Buigues, K. Sekkat, Industrial policy in Europe, Japan and the USA: Amounts, mechanisms and effectiveness, 10 (Palgrave-McMillan, 2009)

9. L. Navarro, Enterprise Papers 2, 3 (2003)

10. D. Rodrik, CEPR Discussion Papers 4767, 16 (2004)

11. A. Panarin, Postmodern Politics: How Comprador Regimes Appear, 196 (2007) http://www.perspektivy.info/oykumena/vector/postmodernistskaya_politika_kak_poya vlyaiutsya_kompradorskie_rezhimy.htm

12. L. Amoroso, Vilfredo Pareto Econometrica 1(6), 1-21 (1938)

13. J. Foreman-Peck, EIB Papers 1(11), 52 (2006)

14. Approval of the State Program for Aviation Development has begun Press Service of the Ministry of Economy https://www.me.gov.ua/News/Detail?lang=ukUA\&id=b55ddcf9-a1a5-4a0b-b7c0e10b7de33566\&title=RozpochalosiaZatverdzhenniaDerzhprogramiZRozvitkuAviatsii.

15. Strategy for the development of domestic aircraft construction until 2030 Ministry of Economic Development, Trade and Agriculture of Ukraine https://drive.google.com/file/d/1YeGDsNaCnZCyKVeKPBTeWzt9vs9ljhHP/view

16. N. Ye. Skorobohatova, A. O. Korchak, Current problems of economics and management 11 (2017) http://ape.fmm.kpi.ua/article/view/103817

17. D. Hubenko, Ukrainian aviation industry: how to get out of a long peak (2016) https://www.dw.com/uk/\%D1\%83\%D0\%BA\%D1\%80\%D0\%B0\%D1\%97\%D0\%BD\% D1\%81\%D1\%8C\%D0\%BA\%D0\%B8\%D0\%B9-

$\%$ D0\%B0\%D0\%B2\%D1\%96\%D0\%B0\%D0\%BF\%D1\%80\%D0\%BE\%D0\%BC-

$\%$ D1\%8F\%D0\%BA-\%D0\%B2\%D0\%B8\%D0\%B9\%D1\%82\%D0\%B8-

$\% \mathrm{D} 1 \% 96 \% \mathrm{D} 0 \% \mathrm{~B} 7-$

$\%$ D0\%B7\%D0\%B0\%D1\%82\%D1\%8F\%D0\%B6\%D0\%BD\%D0\%BE\%D0\%B3\%D0

\%BE-\%D0\%BF\%D1\%96\%D0\%BA\%D0\%B5/a-19388922

18. Report on the results of the analysis of the effectiveness of the application of tax benefits by business entities and their impact on the development of aircraft construction https://rp.gov.ua/upload-files/Activity/Collegium/2019/123_2019/Zvit_12-3_2019.pdf and Report on the management of ANTONOV for 2019 https://www.antonov.com/en/file/s2A6pZoXmOqqk? 